\title{
Is the Business satisfied with University education in Ukraine? (An interview with Vilatiy Bolonkin)
}

\author{
Sergii Rudenko \\ Doctor of Philosophical Sciences, Associate Professor, Taras Shevchenko National \\ University of Kyiv (Kyiv, Ukraine) \\ E-mail: rudenkosrg@gmail.com \\ https://orcid.org/0000-0001-9069-0989
}

Vitaliy Bolonkin

Head of the "Macagrotech" Company (Kalynivka, Kyiv Region, Ukraine)

E-mail: macagrotech@ukr.net

\begin{abstract}
The key criterion for ensuring and assessing the quality of any education, especially higher education is the cooperation between higher education institutions and employers, which, according to the new Law of Ukraine on Higher Education have received the status of participants in the educational process.

However, the question remains about the extent to which this idea is implemented into the real practice of the higher education establishments of Ukraine. It is obvious that the answer to this is an issue that is relevant for the expert environment in Ukraine, which is complex and requires the study of educators and practically practising entrepreneurs expert opinion. This topic, as well as the results of research of such modern authors as Oleg Bazaluk [Bazaluk, 2016], Roman Sapenko [Rudenko, 2018], Iryna Liashenko [Liashenko, 2018], Dmytro Nelipa [Nelipa, 2018], became the basis of a new column of the journal headlined "Is the Business satisfied with the University education of Ukraine?"

The Director of one of the leading and successful enterprises of Kyiv region Vitaly Bolonkin shared his thoughts on this topic in the interview to Sergii Rudenko.
\end{abstract}

Keywords: Higher Education; Business; employers; Ukraine

Received: December 12, 2018; accepted: December 20, 2018

Ukrainian Policymaker, Volume 3, 2018: 85-88.

https://doi.org/10.29202/up/3/11

(C) Rudenko, Sergii, 2018

(C) Bolonkin, Vitaliy, 2018 
Dear Mr. Bolonkin, firstly I would like to appreciate you for taking part in this project to share your experience with a practising entrepreneur and an expert in the field of business administration.

To start the conversation, could you tell about your company and its activities?

I also want to thank you for the invitation to talk about this very difficult, but very important topic. I think, the problem of cooperation between education and the employer remains unresolved in Ukraine.

Our company specializes on the production of boilers, air heaters, generally speaking, reliable, efficient and economical heating systems. The company has been operating on the Ukrainian market since Ukraine gained independence. Our task is to provide innovative heating systems for schools, kindergartens, public buildings, houses, cafes, shops, livestock buildings and the like. The main feature of our production is its alternative to gas heating at the expense of use of such cheap raw materials as heat from firewood and waste of industrial and agricultural production.

How do you, as the employer, could characterize the interaction of your enterprise with the system of higher education? Is there a real practice of such cooperation?

Unfortunately, I must say that the real interaction of my company with higher education institutions is spontaneous, non-systemic and isolated. Basically, communication with teachers is based on personal contacts and, as a rule, only with the heads of higher education establishments. To a greater extent, our company connects research and production activities, cooperation in the field of science and innovation with higher education institutions. However, it has a similar interaction with educational practice.

\section{What are the main reasons for this situation?}

The reasons are many. We can talk about political, economic, social and other factors. Yet, from my point of view, the reason for the lack of interaction with higher education institutions is the discrepancy of their curricula and educational programs to the needs of our company. The practice of training young people directly in the workplace has already become familiar, and, in my opinion, almost everyone has to learn.

So, do you think Ukrainian universities and other higher education institutions prepare specialists who do not meet the needs of your company?

No, that is not exactly true. Higher education institutions of Ukraine provide good theoretical training, including a common culture and worldview. In other words, they develop the general competences, without which the professional activity in our company is impossible. However, as I have already noted, this is not enough to work at the enterprise. In fact, we get an alumnus with a good general training and professional knowledge. Nevertheless, we usually form the special skills we need for our business. This applies to both professionals involved directly in the production and the management staff of the enterprise. 
You mentioned the management staff. Please, tell me whether your company needs managerial personnel, if so, to what extent?

Thus, the need for managerial personnel is particularly acute, despite the fact that their quantitative demand for such workers is much smaller.

\section{Could you clarify these numbers?}

Our company in different historical periods of its existence had a different number of employees. However, it is about 10 percent of the total number of employees involved in the management of the business. Currently, the company has 40 employees, four of whom (including me as a Director) are involved in business administration. In my opinion, without these specialists, the enterprise would cease to exist.

You have passed my next question. Do you think education in the field of business administration in the labour market is necessary today, on the example of the your enterprise? It is especially interesting for our readers.

Yes, of course, we do, because this category of employees is responsible for the future of our business. At the same time, I would like to stress that management professionals should possess certain professional and production skills, even if not to the extent that they are directly responsible for the production cycle. There must be a kind of balance.

Does an alumnus of the Ukrainian University in the field of business administration meet the requirements of the employer in terms of real work practice? Which kind of competences is conform or not?

Unfortunately, I must say that graduates of Ukrainian universities in these specialities are mostly unprepared to work at my enterprise. Usually an alumnus needs to "get used," that is, to obtain additional knowledge, skills. Again, I perform this function at the enterprise directly.

As I said, the University provides high-quality general competence, that is, an understanding of the modern world, economics, business, awareness of the features of the modern world and the like. This is extremely important, but practical training in Ukrainian and International companies remains insufficient.

What are the functions of a specialist in the field of business administration in the real practice of your company? What knowledge, from your point of view, does he lack?

First of all, I would like to talk about personnel work. Personnel specialists (HR) play an important role in my company. Effective and rational selection of personnel, work with existing employees is one of the most important areas in the work of our company. It should be noted that a young University graduate, based on my experience, without experience in the enterprise, is not ready to perform the functions of an HR manager.

The second area is financial management. Any company has the capital that needs to be managed. 
The third section-the organization of production, which is the basis of the enterprise.

If we imagine their hierarchy, then, in my opinion, production comes first, then capital, then personnel.

However, these professional management competences are now acquired in the enterprise itself and not in a higher education institution.

Describe the "ideal" University alumnus, who fits best to your company.

Perhaps 100 percent ready to work in my company graduate institutions of higher education in Ukraine is not able to prepare at all. However, this is possible at 95 percent.

The key competences of such an "ideal graduate" should be soft skills like the ability to solve complex problems related to production, but not directly related to it. These are skills in the field of practical psychology, practical pedagogy and the basics of education; skills of interaction with the media as well as professional and general social networks, business negotiation skills (especially in English); skills to work in a team and in conditions of uncertainty and interdisciplinarity. Undoubtedly, these skills are not enough. We cannot avoid the hard skills. The latter is the basis; however, if we are talking about the "ideal" University alumnus, then hard skills should be supplemented with soft skills.

Thank you, Mr. Bolonkin for your time and interesting conversation.

\section{[C] References}

Bazaluk, Oleg, and Tamara Blazhevych. The Image of an Ideal Ukrainian Politician. Ukrainian National Idea. Future Human Image, 3 (6), 2016: 24-30.

Liashenko, Iryna. Pre-University Training in Ukraine: History and Contemporary Condition. Future Human Image, Volume 10, 2018: 41-49. https://doi.org/10.29202/fhi/10/4

Liashenko, Mykola, and Sergii Rudenko. Is a New Generation of Managers Likely to Come to Small Towns of Ukraine? (An interview with Mykola Liashenko). Ukrainian Policymaker, Volume 2, 2018: 56-62. https://doi.org/10.29202/up/2/8

Nelipa, Dmytro, Oleg Batrymenko, Sergii Rudenko and Iryna Liashenko. Higher education management in Ukraine: will generation change help us transform it faster? Scientific Bulletin of National Mining University. Vol. 3, 2018: 167-175. https://doi.org/10.29202/ nvngu/2018-3/19

Rudenko, Sergii, Roman Sapeńko, Oleg Bazaluk, and Vadym Tytarenko. Management Features of International Educational Projects between Universities of Poland and Ukraine. Naukovyi Visnyk Natsionalnoho Hirnychoho Universytetu. 2, 2018: 142-147. https://doi.org/10.29202/nvngu/2018-2/21 